Eksergi, Vol 18, No. 2

ISSN: $1410-394 \mathrm{X}$

\title{
Pembuatan dan Karakterisasi Biodegradable Plastic Berbasis Campuran Pati dan Selulosa dari Limbah Jagung
}

\section{Fabrication and Characterization of Biodegradable Plastic Based on Mixture of Starch and Cellulose from Corn Waste}

\author{
Ari Susanti $^{\mathrm{a}^{*}}$, Heri Septya Kusuma ${ }^{\mathrm{b}}$, Dhea Kana Zafira ${ }^{\mathrm{a}}$, Arif Bustanul Ilmi ${ }^{\mathrm{a}}$, Iftidha’ul Eka Agustina ${ }^{\mathrm{a}}$, dan Listia Baqih \\ Arie Prayoga $a^{\mathrm{a}}$ \\ ${ }^{a}$ Program Studi Teknik Kimia, Jurusan Teknik Mesin, Fakultas Teknik, Universitas Jember, Jl. Kalimantan Tegalboto 37 \\ Krajan Timur Sumbersari, Jember, 68121, Indonesia \\ ${ }^{b}$ Program Studi Teknik Kimia, Jurusan Teknik Kimia, Fakultas Teknik Industri, Universitas Pembangunan Nasional Veteran \\ Yogyakarta, Jl. SWK 104 (Lingkar Utara) Condongcatur, Yogyakarta, 55283, Indonesia
}

Artikel histori :

Diterima 10 Agustus 2021

Diterima dalam revisi 17 Agustus 202

Diterima 28 Agustus 2021

Online 1 November 2021

\begin{abstract}
ABSTRAK: Bahan makanan membutuhkan kemasan yang tepat untuk mencegah kerusakan. Penggunaan plastik konvensional untuk kemasan telah menimbulkan masalah terhadap lingkungan. Diperlukan suatu pengembangan kemasan yang ramah lingkungan yakni biodegradable plastic. Tujuan penelitian ini adalah melakukan isolasi selulosa dari tongkol jagung dengan tiga prosedur yang berbeda untuk menentukan prosedur terbaik penghasil selulosa dibuktikan dari warna dan hasil uji FTIR. Hasil selulosa terbaik digunakan untuk membuat film biodegradable plastic yang dikombinasikan dengan pati serta campuran plasticizer gliserol, filler sodium montmorillonite nanoclay (SMMT) dan essential oil (EO) daun cengkeh. Film yang sudah dibuat dilanjutkan dengan karakterisasi berupa uji kemampuan degradasi, uji persentase volatility mass fraction, uji persentase swelling degree dan uji persentase water solubility. Dari hasil penelitian ini didapatkan bahwa isolasi selulosa terbaik dihasilkan dengan prosedur 2. Hasil uji kemampuan degradasi film menunjukkan sesuai dengan SNI 7188.7: 2016 dengan hasil degradasi tercepat dalam waktu 4 hari dengan tambahan SMMT. Hasil uji persentase VMF menunjukkan dengan adanya $E O$ dan $S M M T$ pada komposisi menyebabkan nilai persentase $V M F$ rendah. Hasil uji persentase $S D$ menunjukkan, dengan adanya kandungan SMMT menyebabkan nilai persentase $S D$ meningkat sedangkan adanya penambahan $E O$ menyebabkan nilai persentase $S D$ makin rendah. Hasil uji persentase WS menunjukkan, adanya SMMT menyebabkan persentase WS meningkat sedangkan dengan adanya tambahan EO pada variasi komposisi menyebabkan persentase WS menurun.
\end{abstract}

Kata Kunci: biodegradable plastic; essential oil; filler; plasticizer; selulosa

\begin{abstract}
Foodstuffs need proper packaging to prevent spoilage. The use of conventional plastics for packaging has caused environmental problems. It is necessary to develop environmentally friendly packaging as biodegradable plastic. The purpose of this study was to isolate cellulose from corn cobs with three different procedures to determine the best procedure for producing cellulose, as evidenced by the color and results of FTIR analysis. The best cellulose yields are used to make biodegradable plastic films combined with starch and a glycerol plasticizer, sodium montmorillonite nanoclay filler, and clove leaf essential oil. The film that has been made is continued with characterization in the form of analysis of degradation ability, analysis of volatility mass fraction (\%), analysis of swelling degree (\%), and water solubility (\%). The results of this study found that the best cellulose isolation was produced by a procedure 2. The results of the analysis of the degradation ability of the film showed that it was under SNI 7188.7: 2016 with the fastest degradation results within four days with the addition of SMMT. The results of the VMF (\%) analysis showed that the presence of EO and SMMT in the composition causes the VMF (\%) value to be below. The results of the SD (\%) analysis show that the presence of SMMT causes the SD (\%) value to increase while the addition of EO causes the SD (\%) value to decrease. The results of the WS (\%) analysis showed that the presence of SMMT causes the WS (\%) to increase, while the addition of EO to the composition variation causes the WS (\%) to decrease.
\end{abstract}

Keywords: biodegradable plastic; essential oil; filler; plasticizer; cellulose

*Corresponding Author: +12-2345678; fax : +2345 678910

Email: ari.susanti0106@gmail.com 


\section{Pendahuluan}

Meningkatnya permintaan globalisasi pasar dunia, memungkinkan penggunaan kemasan yang dapat memperpanjang umur penyimpanan. Plastik merupakan bahan pengemas yang banyak sekali digunakan (Hijrah \& Purnama Putra Yebi, 2010). Penggunaan plastik yang berlebihan dapat menyebabkan terjadinya pencemaran lingkungan karena plastik merupakan bahan yang sukar terurai secara alami (Nugroho et al., 2018) .

Jagung (Zea Mays L.) adalah salah satu komoditas tanaman pangan yang memiliki peranan dan nilai strategis setelah padi. Tongkol jagung adalah limbah yang diperoleh ketika biji jagung dilepaskan dari buahnya. Limbah tongkol jagung banyak digunakan oleh masyarakat namun pemanfaatannya belum cukup maksimal. Kandungan serat selulosa pada tongkol jagung tinggi yakni $45 \%$ (Howard et al., 2002). Nilai kandungan selulosa yang tinggi pada tongkol jagung dapat dimanfaatkan sebagai bahan baku pembuatan biodegradable plastic yang ramah lingkungan dan dapat terurai oleh alam (Sinaga et al., 2018).

Pati adalah polisakarida yang termasuk terbarukan dan berkelanjutan, berlimpah ruah serta murah. Pati terdiri dari dua jenis makromolekul glukosa, amilosa, dan amilopektin. Pati memiliki sifat termoplastik yang menguntungkan dan dapat terurai secara hayati (Shafqat et al., 2021). Pati singkong memiliki kualitas sangat baik dengan karakteristik warna putih. Biodegradable plastic yang dibuat dari campuran pati memiliki sifat mekanik yang buruk dan rapuh sehingga perlu diperbaiki dengan cara penambahan plasticizer (Mukuze et al., 2019).

Plasticizer adalah ester tidak berwarna dan tidak berbau yang dapat meningkatkan elastisitas suatu bahan. Plasticizer dapat meningkatkan mobilitas rantai polimer dengan mengurangi gaya antarmolekul yang membantu meningkatkan fleksibilitas. Gliserol adalah senyawa alkohol polihidrat dan mempunyai sifat mudah larut dalam air (hidrofilik), dapat meningkatkan viskositas larutan, dan mengikat air. Gliserol juga memiliki berat molekul kecil yakni 92,094 gram/mol sehingga mampu menurunkan gaya intermolekul sepanjang rantai polimernya, yang menjadikan plastik akan lentur (Mukuze et al., 2019).

Sodium montmorillonite nanoclay (SMMT) adalah mineral yang terdiri dari kristal aluminosilikat terhidrasi yang mengandung kation alkali tanah dalam kerangka tiga dimensi. Kemampuan mengembang, sifat penukar ion, luas permukaan yang besar, dan mudah menyerap air merupakan sifat dari SMMT yang mana bisa bermanfaat sebagai filler untuk meningkatkan sifat fisik dan mekanik biodegradable plastic (Iamareerat et al., 2018).

Tanaman cengkeh (Syzigium aromaticum) adalah salah satu tanaman penghasil minyak atsiri. Bagian tanaman cengkeh yang paling banyak menghasilkan minyak adalah daun cengkeh. Minyak cengkeh yang digunakan dalam campuran pembuatan biodegradable plastic ini memiliki aktivitas biologis yang kuat karena terutama mengandung eugenol yang tinggi yakni sekitar 70-80\% (Harunsyah et al., 2019). Minyak cengkeh bisa menghambat pertumbuhan mikroorganisme, membunuh mikroba, dan jamur, serta mengandung antioksidan yang lebih tinggi dibandingkan lemon, anggur, dan ketumbar (Li et al., 2019).

Penelitian ini memiliki tujuan untuk membuat biodegradable plastic dengan memanfaatkan campuran selulosa dari tongkol jagung dan pati singkong yang dikombinasikan dengan gliserol, SMMT, dan EO. Karakteristik film biodegradable plastic ini diamati dari uji degradasi, uji volatility mass fraction, uji sweeling degree, dan uji water solubility.

\section{Metodologi}

Penelitian ini terdiri dari tiga tahapan umum yakni preparasi bahan, isolasi selulosa dari tongkol jagung, dan pembuatan film biodegradable plastic. Pada isolasi selulosa tongkol jagung diberlakukan tiga variasi prosedur, yang mana prosedur terbaik dijadikan sebagai bahan baku selulosa dalam pembuatan film.

\subsection{Bahan}

Penelitian ini menggunakan bahan baku selulosa dari limbah tongkol jagung yang didapatkan dari petani lokal di daerah Rembangan, Desa Kemuning Lor, Kecamatan Arjasa, Kabupaten Jember. Sumber pati yang digunakan berasal dari tepung tapioka merk Cap Pak Tani. Selain itu juga menggunakan bahan-bahan yang tersedia di Laboratorium Operasi Teknik Kimia Program Studi Teknik Kimia Universitas Jember antara lain $\mathrm{NaOH}(5 \%)$, akuades, $\mathrm{NaOCl}(2 \%), \mathrm{HNO}_{3}(2 \%), \mathrm{H}_{2} \mathrm{O}_{2}(2 \%)$, gliserol (99\%), dan SMMT. Sedangkan EO daun cengkeh dibeli dari toko Sumber Atsiri, Cilacap.

\subsection{Preparasi Bahan}

Dalam preparasi bahan baku, tongkol jagung perlu dicacah dan digiling untuk memudahkan proses penghalusan (Kunusa, 2017). Langkah awal tongkol jagung yakni ditimbang, didapatkan kadar air awal 15\%, lalu dijemur di bawah terik matahari selama 8 jam dalam 3 hari. Lalu, tongkol jagung ditimbang lagi dan diukur kadar air akhir $7 \%$. Kemudian, melakukan pencacahan menggunakan palu untuk memperkecil ukuran tongkol jagung dan dilanjutkan dengan memasukkannya ke dalam alat penggilingan hingga menjadi serbuk. Serbuk tongkol jagung diayak agar ukuran serbuknya seragam 80 mesh. Serbuk kemudian disimpan dalam wadah kaca.

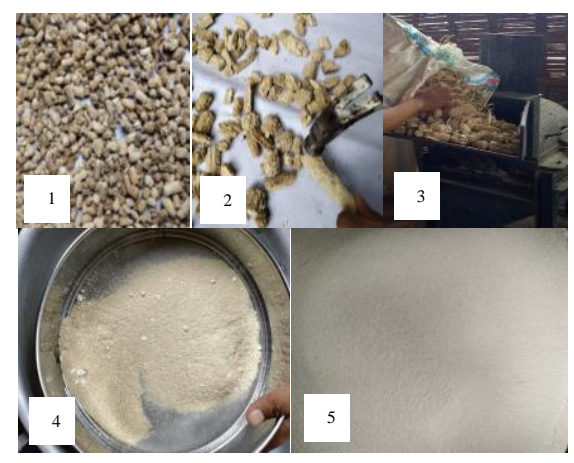

Gambar 1. Proses Preparasi Bahan 
Selanjutnya melakukan uji yang bertujuan untuk mengetahui persentase kandungan selulosa, hemiselulosa, dan lignin yang terdapat dalam sampel. Uji ini dilakukan di Laboratorium Biosains, Politeknik Negeri Jember, menggunakan Metode Chesson.

\subsection{Isolasi Selulosa}

Menggunakan tiga variasi prosedur untuk mendapatkan selulosa tongkol jagung. 10 gram serbuk tongkol jagung berukuran 80 mesh ditambah $800 \mathrm{~mL} \mathrm{NaOH} \mathrm{(5 \% )} \mathrm{diaduk}$ pada suhu ruang selama 1 jam lalu didekantasi. Melakukan filtrasi dengan kain batis. Selanjutnya residu ditambah 180 $\mathrm{mL} \mathrm{NaOCl}(2 \%)$, dipanaskan, dan diaduk pada suhu $70^{\circ} \mathrm{C}$ selama 1 jam. Melakukan filtrasi dengan kain batis. Residu selanjutnya ditambah $\mathrm{HNO}_{3}(2 \%)$ dengan rasio 1:2. Larutan dipanaskan dan diaduk pada suhu $80^{\circ} \mathrm{C}$ selama 1 jam. Melakukan filtrasi dengan kain batis. Pada prosedur 1, diterapkan pengulangan pada penambahan $\mathrm{HNO}_{3}(2 \%)$ dua kali. Pada prosedur 2, diterapkan pengulangan pada penambahan $\mathrm{NaOCl}(2 \%)$ dan penambahan $\mathrm{HNO}_{3}(2 \%)$ dua kali. Sedangkan pada prosedur 3, dilakukan pengulangan dengan penambahan $\mathrm{NaOCl}(2 \%)$ yang diikuti dengan penambahan $\mathrm{H}_{2} \mathrm{O}_{2} \quad(2 \%)$ dengan ratio $1: 1$. Selanjutnya ditambahkan juga $\mathrm{HNO}_{3}(2 \%)$. Pengulangan dilakukan dua kali. Residu hasil pengulangan kemudian dikeringkan dalam oven hingga terbentuk serbuk selulosa kering (Sinaga et al., 2018).

\subsection{Uji FTIR (Fourier Transform Infrared Spectroscopy)}

Uji ini bertujuan untuk mengetahui gugus fungsi secara kualitatif pada sampel. Sampel di run dengan alat Shimadzu IR Tracer 100 dengan panjang gelombang 4500 $\mathrm{cm}^{-1}-400 \mathrm{~cm}^{-1}$ di Laboratorium Polimer dan Membran, Jurusan Teknik Kimia, Universitas Surabaya.

\subsection{Pembuatan Film Biodegradable Plastic}

Film dibuat dari hasil isolasi selulosa terbaik yakni prosedur 2. Membuat empat variasi film yang berbeda. Variasi pertama yakni campuran 1 gram selulosa dan 5 gram pati ditambahkan 1,5 mL gliserol sebagai plasticizer lalu ditambah akuades sebanyak 92,5 mL. Variasi kedua film yaitu campuran 1 gram selulosa dan 5 gram pati ditambahkan 1,5 mL gliserol juga 1 gram SMMT sebagai filler, serta ditambahkan akuades sebanyak 91,5 mL. Variasi film ketiga hampir sama dengan variasi kedua, namun $S M M T$ yang digunakan sebanyak 5 gram dan akuades 91,5 mL. Sedangkan variasi film keempat yakni campuran 1 gram selulosa dan 5 gram pati, ditambah 1,5 $\mathrm{mL}$ gliserol, lalu ditambah 5 gram SMMT dan $2 \mathrm{~mL} E O$. Keempat variasi film diberlakukan prosedur sama yakni diaduk selama 1 jam dengan kecepatan 400 rpm pada suhu ruang. Selanjutnya larutan dicetak dalam cetakan kaca yang dilapisi aluminium foil. Kemudian dimasukkan oven dengan mengatur suhu pada $70^{\circ} \mathrm{C}$ selama 1 jam. Film yang terbentuk lalu dilepaskan dari cetakan kaca dan dipotong dengan ukuran $2 \mathrm{~cm} \mathrm{X} 2 \mathrm{~cm}$ dan dibungkus dengan aluminium foil lalu disimpan dalam desikator untuk karakterisasi.

\subsection{Uji Kemampuan Degradasi}

Uji ini bertujuan untuk mengetahui kemampuan suatu biodegradable plastic dapat terurai dengan baik di lingkungan. Uji ini dilakukan secara aerobic dan menggunakan metode soil burial. Sampel berukuran $2 \mathrm{~cm}$ X $2 \mathrm{~cm}$ ditanam di dalam pot berisi tanah sampai seluruh bagian sampel menyatu dengan tanah atau terdegradasi sempurna. Sampel dibiarkan terkena udara terbuka. Pengamatan dilakukan dengan melakukan penimbangan massa sampel sebelum dan sesudah pengamatan (Hidayat et al., 2015). Dihitung pula \% fraksi massa residual dengan persamaan (1) sebagaimana berikut ini.

fraksi massa residual $(\%)=\frac{\text { massa sampel setelah penimbangan }}{\text { massa sampel sebelum penimbangan }} \times 100$

\subsection{Uji Volatility Mass Fraction}

Uji ini dilakukan dengan cara sampel film yang berukuran $2 \mathrm{~cm}$ X $2 \mathrm{~cm}$ ditimbang massanya, sebelum dikeringkan ( $\mathrm{W}_{\mathrm{a}}$ dalam gram) dan setelah dikeringkan $\left(\mathrm{W}_{\mathrm{b}}\right.$ dalam gram) ke dalam oven pada suhu $105^{\circ} \mathrm{C}$ selama 24 jam dan dihitung persentase volatility mass fraction yang menunjukkan persentase pengurangan massa sampel (Li et al., 2019) sesuai dengan persamaan (2).

$$
V_{m}(\%)=\frac{\left(W_{a}-W_{b}\right)}{W_{a}} \times 100
$$

Dimana $V_{m}$ adalah persentase volatility mass fraction.

\subsection{Uji Swelling Degree dan Water Solubility}

Uji ini bertujuan untuk mengetahui kemampuan sampel dalam menyerap air dan dilakukan dengan cara potongan sampel dalam kondisi kering ( $\mathrm{W}_{1}$ dalam gram) ditempatkan dalam beaker glass berukuran $100 \mathrm{~mL}$ yang berisi $30 \mathrm{~mL}$ akuades kemudian ditutup dengan aluminium foil dan dibiarkan pada suhu ruang $\left(25^{\circ} \mathrm{C}\right)$ selama 24 jam. Sampel kemudian diambil lalu ditimbang ( $\mathrm{W}_{2}$ dalam gram) ( $\mathrm{Li}$ et al., 2019) dan dihitung persentase swelling degree mengikuti persamaan (3).

$$
S D(\%)=\frac{\left(W_{2}-W_{1}\right)}{W_{1}} \times 100
$$

Dimana $S D$ adalah persentase sweeling degree.

Selanjutnya sampel basah tadi dikeringkan dalam oven pada suhu $50^{\circ} \mathrm{C}$ selama 24 jam untuk ditimbang kembali sebagai massa akhir sampel $\left(\mathrm{W}_{3}\right.$ dalam gram) dan dihitung persentase kelarutan film dalam air (Li et al., 2019) sesuai dengan persamaan (4).

$$
W S(\%)=\frac{\left(W_{1}-W_{3}\right)}{W_{3}} \times 100
$$

Dimana WS adalah persentase water solubility.

\section{Hasil dan Pembahasan \\ 3.1 Preparasi Bahan}

Ukuran serbuk berpengaruh terhadap selulosa yang dihasilkan. Ukuran serbuk yang kecil, akan mempercepat laju reaksi selama proses pencampuran bahan (Wiradipta, 2017).

Hasil uji terhadap serbuk tongkol jagung disajikan dalam tabel 1 di bawah ini. 
Tabel 1. Hasil Uji Parameter \% Kandungan Serbuk Tongkol Jagung

\begin{tabular}{|c|c|c|c|}
\hline No. & Parameter & Satuan & Hasil Uji \\
\hline 1. & Selulosa & $\%$ & 50,200 \\
\hline 2. & Hemiselulosa & $\%$ & 31,800 \\
\hline 3. & Lignin & $\%$ & 5,275 \\
\hline
\end{tabular}

Tabel 1 menunjukkan bahwa tingginya persentase kandungan selulosa dalam serbuk tongkol jagung yakni $50,2 \%$ menunjukkan bahwa serbuk tongkol jagung memiliki potensi yang sangat tinggi sebagai bahan baku dari isolasi selulosa untuk pembuatan biodegradable plastic.

\subsection{Isolasi Selulosa}

Isolasi selulosa berfungsi untuk mendapatkan selulosa dari serbuk tongkol jagung dengan menghilangkan hemiselulosa dan lignin. Menerapkan tiga variasi prosedur untuk mencari prosedur mana yang terbaik dalam menghasilkan selulosa. Metode terbaik ditandai dengan adanya gugus fungsi selulosa yang ditunjukkan dari hasil uji FTIR serta warna selulosa yang paling putih.

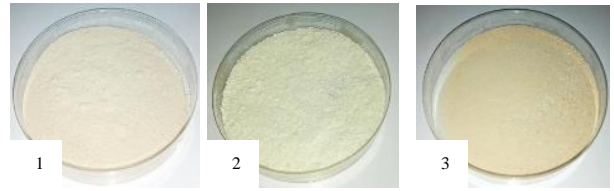

Gambar 2. Hasil Isolasi Selulosa Pada Berbagai Prosedur

Gambar 2 menunjukkan perbedaan warna selulosa dari tiga variasi prosedur. Dari pengamatan visual dapat diketahui bahwa selulosa prosedur 2 memiliki warna paling putih. Hal ini diduga karena proses dehemiselulosa yang berhasil yakni pada saat sampel dicampur dengan $\mathrm{NaOH}$ (5\%). Hemiselulosa larut dalam pelarut basa. Pada saat pemanasan, hemiselulosa melunak dan terpisah. Selain itu, proses delignifikasi diduga sudah berhasil dengan mencampurkan $\mathrm{HNO}_{3}$ (2\%). Asam kuat dapat menghancurkan daerah amorf serat selulosa dan pada suhu tinggi $\left(80^{\circ} \mathrm{C}\right)$ memecah lignin menjadi partikel yang kemudian terlepas dari selulosa (Kunusa, 2017). Waktu yang digunakan dalam proses pemanasan dan pengadukan dalam penelitian ini adalah 1 jam yang juga merupakan waktu optimum dalam proses penurunan kadar lignin dan proses penghilangan kadar hemiselulosa (Asmoro et al., 2018) (Rewini \& Kunusa Hendri, 2017). Sedangkan selulosa prosedur 1 menunjukkan secara visual memiliki warna coklat muda dan selulosa prosedur 3 menunjukkan warna selulosa coklat agak gelap karena masih adanya kandungan lignin di dalamnya (Kunusa, 2017) (Puji et al., 2013).

\subsection{Uji FTIR (Fourier Transform Infrared Spectroscopy)}

Uji FTIR memungkinkan karakterisasi struktur kimia dengan mengidentifikasi gugus fungsi yang ada pada sampel. Spektrum inframerah selulosa, hemiselulosa, dan lignin dipelajari dalam literatur dan gugus fungsi yang khas serta pita yang sesuai untuk setiap komponen telah dijelaskan (Morán et al., 2008). Semua sampel disajikan dua daerah absorbansi utama. Yang pertama pada bilangan gelombang rendah kisaran 713,67-1762,97 $\mathrm{cm}^{-1}$ dan yang kedua pada bilangan gelombang yang lebih tinggi sesuai dengan kisaran 2890,38-4000 $\mathrm{cm}^{-1}$. Puncak penyerapan spesifik dapat diidentifikasi pada setiap komponen (Gambar 3). Puncak serapan pada bilangan gelombang di dekat $2995 \mathrm{~cm}^{-1}$ merupakan ciri khas dari selulosa (Saifuddin et al., 2013). Besarnya kandungan selulosa pada prosedur 2 ditunjukkan oleh besarnya daerah serapan yang lebar yakni pada bilangan gelombang 3345,59-4000 $\mathrm{cm}^{-1}$. Lebarnya puncak serapan yang terbentuk pada bilangan gelombang tersebut menunjukkan adanya ikatan intrapolimer ataupun interpolimer yang kuat yang merupakan ciri dari selulosa (Morán et al., 2008) (Pratama et al., 2019). Adanya sejumlah kecil hemiselulosa yang mengandung ikatan $\mathrm{C}=\mathrm{O}$ ditunjukkan pada bilangan gelombang $1734,99 \mathrm{~cm}^{-1}$.

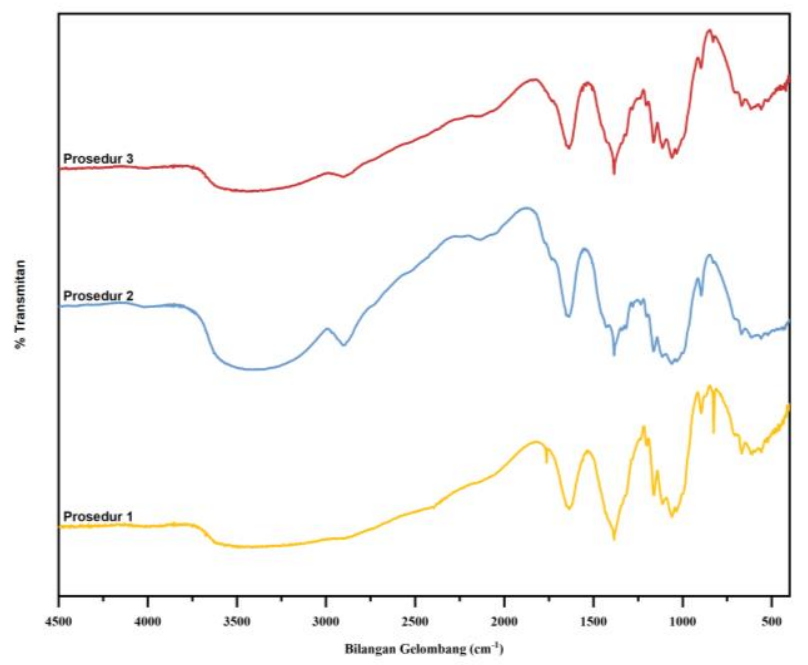

Gambar 3. Spektrum FTIR Untuk Ketiga Prosedur Isolasi Selulosa

Lignin disajikan dengan adanya kehadiran gugus fungsi seperti metoksil-O- $\mathrm{CH}_{3}, \mathrm{C}-\mathrm{O}-\mathrm{C}$, aromatik $\mathrm{C}=\mathrm{C}$, dan aromatik C-H (Morán et al., 2008) (Pangau et al., 2017). Pada prosedur 1 , aromatik $\mathrm{C}=\mathrm{C}$ muncul di beberapa puncak serapan yakni 1521,66; 1532,47; 1542,11; dan 1560,44 $\mathrm{cm}^{-}$ 1. Aromatik C-H juga muncul pada beberapa puncak serapan yakni 713,$67 ; 782,15 ; 789,86 ; 800,47 ; 806,25$; 825,55 ; dan $895,95 \mathrm{~cm}^{-1}$. Gugus fungsi $\mathrm{O}-\mathrm{CH}_{3}$ juga muncul pada bilangan gelombang 1430,24 $\mathrm{cm}^{-1}$. Banyaknya serapan yang menunjukkan gugus fungsi tersebut menyatakan bahwa prosedur 1 masih banyak mengandung lignin selain sejumlah kecil selulosa pada rentang 3355,23$4000 \mathrm{~cm}^{-1}$ dan sejumlah kecil hemiselulosa yang mengandung ikatan $\mathrm{C}=\mathrm{O}$ yang ditunjukkan pada bilangan gelombang $1762,97 \mathrm{~cm}^{-1}$. Hal ini sesuai dengan penelitian yang menyatakan bahwa semakin tinggi kandungan lignin maka semakin rendah kadar selulosa pada sampel, begitu juga sebaliknya (Wiradipta, 2017). Pada prosedur 3, aromatik $\mathrm{C}=\mathrm{C}$ muncul pada puncak serapan 1506,43 dan $1632,77 \mathrm{~cm}^{-1}$. Puncak serapan C-O-C juga muncul di prosedur 3 pada bilangan gelombang 1215,17; 1248,93, dan $1237,36 \mathrm{~cm}^{-1}$. Juga aromatik $\mathrm{C}-\mathrm{H}$ yang muncul pada bilangan gelombang 829,$41 ; 896,91$; dan $897,88 \mathrm{~cm}^{-1}$. Hal ini menunjukkan bahwa prosedur 3 juga banyak 
mengandung lignin dengan sedikit selulosa pada rentang bilangan gelombang 3096,77-4000 $\mathrm{cm}^{-1}$ tanpa terbentuk hemiselulosa (Morán et al., 2008). Sehingga dari uji gugus fungsi menggunakan FTIR menunjukkan prosedur 2 adalah yang terbaik dalam menghasilkan selulosa untuk dijadikan bahan baku pembuatan biodegradable plastic.

\subsection{Pembuatan Biodegradable Plastic}

Pada proses pembuatan biodegradable plastic, penggunaan SMMT yang berukuran nano bisa menyebabkan bahan lain yang berukuran lebih besar teraglomerasi sehingga digunakan pengadukan cepat $400 \mathrm{rpm}$ untuk menciptakan larutan homogen (Ulfah \& Nugraha, 2014). Film biodegradable plastic yang terbentuk lalu dikarakterisasi.

\subsection{Uji Kemampuan Degradasi}

Uji kemampuan degradasi dilakukan untuk mengetahui ketahanan biodegradable plastic film terhadap mikroba pengurai, kelembababan tanah, suhu, dan faktor fisiko kima yang terdapat dalam tanah. Hasil uji kemampuan degradasi yang ditunjukkan Gambar 4, dapat diketahui bahwa dari keempat sampel mengalami degradasi sempurna dalam waktu yang cepat yakni kurang dari 11 hari. Variasi TSMMT-EO terdegradasi sempurna dalam waktu 5 hari karena bahan selulosa dan gliserol bersifat hidrofilik, yang mana gliserol cocok untuk bahan hidrofobik seperti pati karena cukup efektif mengurangi ikatan hidrogen internal antar gugus hidroksil sehingga akan meningkatkan jarak intermolekul (Sofia et al., 2017)(Purnavita et al., 2020). Variasi SMMT1 dan SMMT5 terdegradasi sempurna dalam waktu 4 hari karena hidrasi kation yang ada dalam SMMT memberikan sifat hidrofilik dimana kation natrium dapat mengambil air yang menciptakan jarak antar lapisan (Stiller, 2008). Sedangkan variasi SMMT5-EO2 dapat terdegradasi sempurna dalam waktu 10 hari karena pada variasi ini terdapat komponen essential oil daun cengkeh yang bersifat hidrofobik juga memiliki sifat antimikroba, antibakteri, yang mana bisa menghambat aktivitas bakteri, patogen pembusuk, maupun jamur. Hal ini menyebabkan film mengalami perlambatan dalam terdegradasi dibandingkan dengan variasi tanpa essential oil (Hidayati et al., 2015)(Li et al., 2019). Semua variasi biodegradable plastic memenuhi SNI 7188.7: 2016 yang menyatakan bahwa biodegradable plastic terdegradasi $100 \%$ kurang dari 28 hari (Wati \& Abdillah, 2019).

\subsection{Uji Volatility Mass Fraction}

Hasil persentase $V M F$ pada Gambar 5 menunjukkan bahwa variasi komposisi dengan campuran EO daun cengkeh menunjukkan persentase lebih rendah daripada variasi komposisi murni tanpa SMMT dan EO. Hal ini diduga karena beberapa hal yakni interaksi hirofobik yang kuat oleh $E O$ menghasilkan peningkatan sifat hidrofobik. Hal kedua, diduga karena emulsi tetesan $E O$ secara bertahap tertanam di celah molekul yang dapat menyebabkan struktur spasial molekul menjadi lebih padat dan menyebabkan sedikit penguapan molekul air dan EO. Yang ketiga, diduga $E O$ dapat mengganggu distribusi kristal amorf dalam matriks polimer, mengurangi rantai polimer penutup untuk memperbesar bagian kristal. Dengan meningkatkan bagian kristalin dalam matriks, volume bebas antar molekul bisa berkurang, mengakibatkan kemerosotan dalam film untuk menahan dan menangkap molekul air (Li et al., 2019). Persentase $V M F$ pada variasi SMMT1 dan SMMT5 rendah, diduga karena kehadiran SMMT dalam komposisi film dapat meningkatkan kristalitas pada film. Peningkatan kristalitas pada film akan menurunkan permeabilitas uap dan gas. Kristalitas juga akan mengurangi volume bebas dalam polimer plastik sehingga uap dan gas sulit menembus dan masuk polimer. $S M M T$ juga membentuk struktur polimer zig zag yang membuat uap dan gas sulit keluar (Ulfah \& Nugraha, 2014).

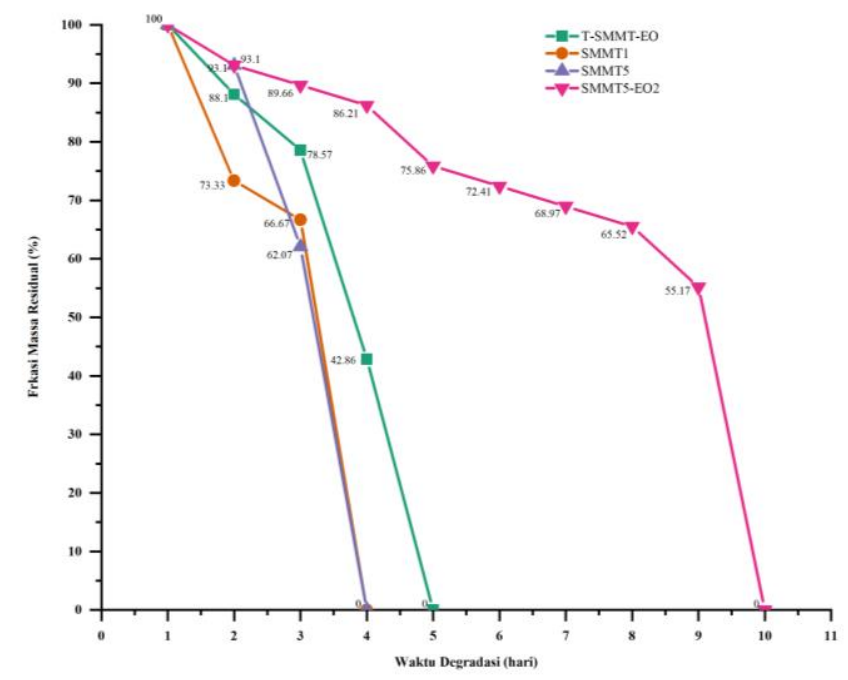

Gambar 4. Perbandingan Kemampuan Degradasi Empat Variasi Komposisi

\subsection{Uji Swelling Degree dan Water Solubility}

Uji persentase $S D$ mengacu pada kemampuan hidrofilik bahan yang merupakan indikator retensi air dari film. Pada varian tanpa $S M M T$ dan tanpa $E O$ maka sifat yang dimiliki hidrofilik. Varian dengan tambahan SMMT yang makin besar menyebabkan sifat hidrofiliknya makin besar pula sehingga nilai persentase $S D$ semakin tinggi. Sedangkan pada varian yang mendapatkan tambahan $E O$ maka akan meningkatkan sifat hidrofobiknya sehingga nilai persentase $S D$ yang semula tinggi akan mengalami penurunan. Hal ini disebabkan karena $E O$ yang mengikat serta interaksi antarmolekul yang kuat dari ikatan hidrogen yang mengurangi jumlah grup yang tersedia dalam jaringan yang mampu membentuk ikatan hidrogen dengan molekul air sehingga mengurangi nilai persentase $S D$ (Li et al., 2019).

Persentase WS bisa dianggap sebagai indikator untuk mengevaluasi ketahanan air dan stabilitas film karena menjadi dasar ketahanan kelembaban eksternal dari film itu sendiri. Variasi komposisi film yang menggunakan selulosa sebagai bahan dasar tentunya memberikan sifat yang didominasi kekakuan dan gaya antar rantai tinggi akibat selulosa yang tidak larut dalam air karena memiliki tiga gugus hidroksil, dimana ini memungkinkan selulosa untuk 
membentuk banyak ikatan hidrogen. SMMT adalah material yang memiliki sifat hidrofilik sehingga mampu menurunkan gaya intermolekul pada biodegradable plastic yang menyebabkan nilai persentase WS nya naik. Makin besar kandungan SMMT maka makin besar persentase WS nya (Yoleva et al., 2016). Nilai persentase $W S$ semakin berkurang dengan adanya penambahan $E O$ dalam variasi komposisi. EO bereaksi lebih efektif sehingga ini akan menyulitkan molekul air untuk memasuki matriks dan menyebabkan jumlah kelompok hidrofilik berkurang. Dengan makin banyak EO maka mengakibatkan penghancuran ikatan hidrogen antara molekul film dan dapat mengganggu serangan air yang mana sebenarnya bisa meningkatkan integritas dan menghasilkan sifat waterproofing pada film (Li et al., 2019).

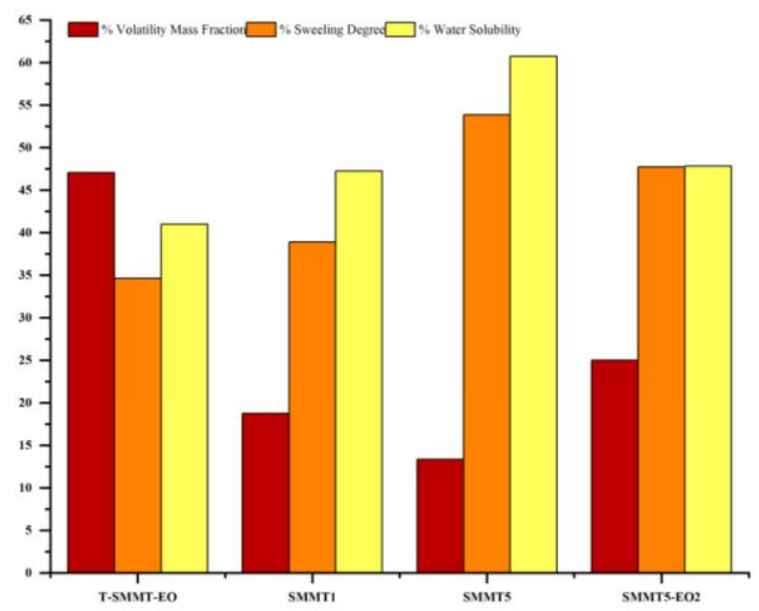

Gambar 5. Hasil Uji Volatility Mass Fraction, Swelling Degree, Dan Water Solubility Pada Berbagai Variasi Komposisi Film

\section{Kesimpulan}

Hasil penelitian ini menunjukkan bahwa tongkol jagung berpotensi menjadi bahan baku pembuatan biodegradable plastic karena memiliki kandungan selulosa yang besar yakni $50,2 \%$. Hasil isolasi selulosa terbaik dihasilkan dengan prosedur 2 dibuktikan dari sifat fisik dan hasil uji FTIR. Hasil uji kemampuan degradasi film menunjukkan sesuai dengan SNI 7188.7: 2016 dengan hasil degradasi tercepat dalam waktu 4 hari dengan variasi komposisi mengandung SMMT. Hasil uji persentase $V M F$ menunjukkan dengan adanya $E O$ pada komposisi, menyebabkan nilai persentase $V M F$ rendah. Begitu juga dengan kandungan SMMT menyebabkan persentase $V M F$ rendah. Hasil uji persentase $S D$ menunjukkan bahwa dengan adanya kandungan SMMT menyebabkan nilai persentase $S D$ meningkat sedangkan adanya penambahan $E O$ menyebabkan nilai persentase $S D$ makin rendah. Hasil uji persentase $W S$ menunjukkan bahwa adanya $S M M T$ menyebabkan persentase WS meningkat sedangkan dengan adanya tambahan EO pada variasi komposisi, menyebabkan persentase WS menurun.

\section{Ucapan Terima kasih}

Terima kasih penulis sampaikan kepada Lembaga Penelitian dan Pengabdian kepada Masyarakat Universitas Jember atas pendanaan penelitian ini melalui skema penelitian kompetisi Hibah Dosen Pemula Tahun 2021.

\section{Daftar Pustaka}

Asmoro, N., Afriyanti, A., \& Ismawati, I. (2018). Ekstraksi Selulosa Batang Tanaman Jagung (Zea Mays) Metode Basa. Jurnal Ilmiah Teknosains, 4, 24. https://doi.org/10.26877/jitek.v4i1.1710

Harunsyah, Yunus, M., \& Fauzan, R. (2019). Effect of Clove Essential Oil Addition on Characteristics of Cassava Starch Bioplastic Film Incorporated Zinc Oxide-Organoclay as Reinforcement.

Hidayat, R., Mulyadi, S., \& Handani, S. (2015). Pengaruh Penambahan Pati Talas Terhadap Sifat Mekanik Dan Sifat Biodegradabel Plastik Campuran Polipropilena Dan Gula Jagung.

Hidayati, S., Zuidar, A. S., \& Ardiani, A. (2015). Aplikasi Sorbitol Pada Produksi Biodegradable Film Dari Nata De Cassava. Reaktor, 15(3), 195. https://doi.org/10.14710/reaktor.15.3.195-203

Hijrah, \& Purnama Putra Yebi, Y. (2010). Studi Pemanfaatan Sampah Plastik Menjadi Produk dan Jasa Kreatif. Jurnal Sains Dan Teknologi Lingkungan, Vol 2, No 1 (2010): SAINS \& TEKNOLOGI LINGKUNGAN. http://journal.uii.ac.id/index.php/JSTK/article/view/3 579

Howard, R. L., Rensburg, E. J. van, \& Abotsi, E. (2002). Lignocellulose biotechnology: Issues of bioconversion and enzyme production. African Journal of Biotechnology (ISSN: 1684-5315) Vol 2 Num 12, 2. https://doi.org/10.5897/AJB2003.0001115

Iamareerat, B., Singh, M., Sadiq, M., \& Anal, A. (2018). Reinforced cassava starch based edible film incorporated with essential oil and sodium bentonite nanoclay as food packaging material. Journal of Food Science and Technology, 55. https://doi.org/10.1007/s13197-018-3100-7

Kunusa, W. R. (2017). Kajian Tentang Isolasi Selulosa Mikrokristalin (SM) dari Limbah Tongkol Jagung. Jambura Journal of Educational Chemistry, Vol 12, No 1 (2017): Februari, 105-108. http://ejurnal.ung.ac.id/index.php/jjec/article/view/22 16

Li, Z., Lin, S., An, S., Liu, L., Hu, Y., \& Wan, L. (2019). Preparation, characterization and anti-aflatoxigenic activity of chitosan packaging films incorporated with turmeric essential oil. International Journal of Biological Macromolecules, 131, 420-434. https://doi.org/https://doi.org/10.1016/j.ijbiomac.201 9.02.169

Morán, J. I., Alvarez, V. A., Cyras, V. P., \& Vázquez, A. (2008). Extraction of Cellulose and Preparation of Nanocellulose from Sisal Fibers. Cellulose, 15, 149- 
159. https://doi.org/10.1007/s10570-007-9145-9

Mukuze, S., Magut, H., \& Mkandawire, F. (2019). Comparison of Fructose and Glycerol as Plasticizers in Cassava Bioplastic Production. Advanced Journal of Graduate Research, 6, 41-52. https://doi.org/10.21467/ajgr.6.1.41-52

Nugroho, A., Rahmad, R., \& Suhartoyo, S. (2018). Pemanfaatan Limbah Plastik Sebagai Energy Alternatif. Simetris: Jurnal Teknik Mesin, Elektro Dan Ilmu Komputer, 9, 55-60. https://doi.org/10.24176/simet.v9i1.1772

Pangau, J. R., Sangian, H. F., \& Lumi, B. M. (2017). Karakterisasi Bahan Selulosa Dengan Iradiasi Pretreatment Gelombang Mikro Terhadap Serbuk Kayu Cempaka Wasian (Elmerillia Ovalis) Di Sulawesi Utara. Jurnal MIPA, 6(1), 53. https://doi.org/10.35799/jm.6.1.2017.16157

Pratama, J. H., Rohmah, R. L., Amalia, A. N., \& Saraswati, T. E. (2019). Isolasi Mikroselulosa dari Limbah Eceng Gondok (Eichornia crassipes) dengan Metode Bleaching-Alkalinasi. ALCHEMY Jurnal Penelitian Kimia, 15 , 239. https://doi.org/10.20961/alchemy.15.2.30862.239250

Puji, Lestari Titi Nur, H., Siti Hanum Indah, L., \& Djagal Wiseso, M. (2013). Pengembangan Teknologi Pembuatan Biopolimer Bernilai Ekonomi Tinggi Dari Limbah Tanaman Jagung (Zea Mays) Untuk Industri Makanan: Cmc (Carboxymethylcellulose). Program Kreativitas Mahasiswa - Penelitian, PKM-P 2013. http://artikel.dikti.go.id/index.php/PKMP/article/view/63

Purnavita, S., Subandriyo, D., \& Anggraeni, A. (2020). Penambahan Gliserol terhadap Karakteristik Bioplastik dari Komposit Pati Aren dan Glukomanan. METANA, 16, 19-25. https://doi.org/10.14710/metana.v16i1.29977

Rewini, W., \& Kunusa Hendri, I. (2017). Studi Tentang Metode Merzerisasi Terhadap Perolehan Total Yield Lignoselulosa. Jambura Journal of Educational Chemistry, Vol 12, No 2 (2017): Agustus, 225-230. http://ejurnal.ung.ac.id/index.php/jjec/article/view/21 82
Saifuddin, N. M., Hussein, R., \& Palanisamy, K. (2013). Microwave-Assisted Alkaline Pretreatment and Microwave Assisted Enzymatic Saccharification of Oil Palm Empty Fruit Bunch Fiber for Enhanced Fermentable Sugar Yield. Journal of Sustainable Bioenergy Systems, 3, 7-17. https://doi.org/10.4236/jsbs.2013.31002

Shafqat, A., Al-Zaqri, N., Tahir, A., \& Alsalme, A. (2021). Synthesis and characterization of starch based bioplatics using varying plant-based ingredients, plasticizers and natural fillers. Saudi Journal of Biological Sciences, 28(3), 1739-1749. https://doi.org/https://doi.org/10.1016/j.sjbs.2020.12. 015

Sinaga, M., Gea, S., Panindia, N., \& Sihombing, Y. A. (2018). The Preparation of All-Cellulose Nanocomposite Film from Isolated Cellulose of Corncobs as Food Packaging. Oriental Journal of Chemistry, 34, 562-567. https://doi.org/10.13005/ojc/340166

Sofia, A., Prasetya, A. T., \& Kusumastuti, E. (2017). Komparasi Bioplastik Kulit Labu Kuning-Kitosan dengan Plasticizer dari BerbagaVariasi Sumber Gliserol. Indonesian Journal of Chemical Science, 6(2), 1-7. http://journal.unnes.ac.id/sju/index.php/ijcs

Stiller, B. (2008). The Effect Of Montmorillonite Nanoclay On Mechanical And Barrier Properties Of Mung Bean Starch Films. Clemson University.

Ulfah, F., \& Nugraha, I. (2014). Pengaruh Penambahan Montmorillonit Terhadap Sifat Mekanikkomposit Film Karagenan-Montmorilonit. Molekul, 9, 155. https://doi.org/10.20884/1.jm.2014.9.2.163

Wati, P. R., \& Abdillah, H. (2019). Effect Of Temperature And Time For Bioplastic From Tapioca Starch.

Wiradipta, I. D. G. A. (2017). Pembuatan Plastik Biodegradable Berbahan Dasar Selulosa Dari Tongkol Jagung [Institut Teknologi Sepuluh Nopember]. https://repository.its.ac.id/id/eprint/46898

Yoleva, A., Djambazov, S., \& Michailov, G. (2016). Organic modification of Bulgarian bentonite by an easy low cost method. 51, 275-280. 